\title{
Olhares da caserna na preservação de autonomias militares durante o processo de redemocratização no Brasil
}

\section{Miradas del Ejército en la preservación de las autonomías militares en el proceso de redemocratización en Brasil}

Resumo: Pretendemos com o presente artigo analisar a visão do Exército na Nova República, referente à distensão iniciada no regime militar (1964-1985), a formação da Constituinte e o quadro tutelar empreendido no governo Sarney. Nesse artigo, utilizaremos dissertações e teses de oficiais do Exército da Escola de Comando e Estado-Maior do Exército (ECEME). Tendo em vista que o controle político sobre a defesa no Brasil, durante um bom período de sua história republicana, esteve sob o controle dos militares, especialmente no período ditatorial, a manutenção dos interesses castrenses no processo de redemocratização se fez presente naquele momento, bem como influenciou no imaginário político dos oficiais nos novos tempos democráticos.

Palavras-chave: Democracia, Nova República, Exército.

Resumen: Tenemos como objetivo en este presente artículo analizar la visión del Ejército en la Nova República, referente a la distensión en el régimen militar (19641985), la formación de la Constituyente y el cuadro tutelar emprendido en el gobierno Sarney. En ese artículo, utilizaremos disertaciones y tesis de los oficiales del Ejército de la Escola de Comando e Estado-Maior do Exército (ECEME).En vista del control político en la defensa brasileña que, ejercido en lo largo tiempo republicano, estuvo bajo el control de los militares, especialmente en el periodo dictatorial, la manutención de los intereses del Ejército en el proceso de redemocratización hizo presente en aquel instante, así como influenció en el imaginario político de los oficiales en los nuevos tiempos democráticos.

Palabras-clave: Democracia, Nueva República, Ejército.

${ }^{*}$ UNESP/FRANCA 


\section{Um histórico antirrepublicano: o controle das Forças Armadas na defesa brasileira}

$\mathrm{Na}$ história republicana brasileira as relações entre militares e civis se deram, em muitos momentos, por meio de disputas políticas dentro do controle do poder político e, também, em torno da manutenção do domínio das Forças Armadas na administração dos assuntos em defesa no país. Ilustrativamente, quando analisamos a história do pensamento em defesa no Brasil vemos que, ao longo dos tempos, tal política pública não fora construída pela sociedade civil brasileira. A partir desse cenário, nota-se que a condução dessas políticas foi realizada por grupos militares, sem a presença ativa da população ou dos representantes dessa sociedade em inúmeras situações.

Desde a proclamação da República, a atuação interventora dos militares se fez presente, sendo que até 1930, apenas o Exército já contabilizava onze ações desse tipo (CARVALHO, 2005, p. 22). Interessante ressaltar a diversidade dos movimentos interventores, pois muitas vezes a corporação não atuou de forma conjunta, ou seja, dependendo da intervenção na Primeira República, elas foram lideradas por oficiais superiores, praças ou alunos.

$\mathrm{Na}$ década de 1940, oficiais do Exército estabeleceram os embasamentos teóricos que seriam utilizados para fundamentar o golpe cívico-militar de 1964 duas décadas depois. Nos governos de Getúlio Vargas, Eurico Dutra, Café Filho, Juscelino Kubitschek, Jânio Quadros e João Goulart, ocorreram intensos debates entre os meios militares quanto ao modo interventor na esfera política. Importante ressaltar que muitas vezes esses debates eram respaldados por grupos políticos. Além de seu papel na arena política, os chefes militares desse período, admiradores do Estado fascista italiano e do Estado nazista alemão, começaram a desenhar o pensamento de um Brasil Potência. A criação da Escola Superior de Guerra (ESG), em 1949, traduziu bem essa perspectiva (MARQUES, 2001, p. 41). Devido à polarização ideológica da Guerra Fria, influenciada pelo National War College estadunidense, essa instituição serviu de apoio à construção de um projeto político, cujas principais finalidades eram combater o comunismo e levar o Brasil ao status de "grande potência". Esse órgão esteve ligado à Doutrina de Segurança Nacional (DSN), herdada dos EUA. Boa parcela do pensamento em defesa no Regime Militar (1964-1985) esteve vinculada ao 


\title{
Revista Brasileira de História \& Ciências Sociais - RBHCS
}

Vol. $8 \mathrm{~N}^{\mathrm{o}}$ 16, Julho - Dezembro de 2016

conceito estratégico nacional que se fez presente na geopolítica do general Golbery Couto e Silva.

Em vista dessa formação, transcorridas algumas décadas, os militares deixaram de intervir parcialmente no sistema político nacional e atuaram na tomada do poder de um governo civil na década de 1960. Alicerçado na DSN, o Exército, contando com o apoio de uma parcela significativa da sociedade civil e, também, com o apoio dos EUA, derrubou o fragilizado governo de João Goulart, acusado de conspirar a favor de um levante comunista no país. Dentro do Exército, a tese de que os militares exerceram sua missão salvadora ao derrubar o governo Goulart manteve-se viva desde então:

\begin{abstract}
A história de 31 de março de 64 vem sendo contada e distorcida com veemência pelos alinhados com o governo deposto e contrários ao êxito desse movimento que desmantelou, da noite para o dia, sem qualquer derramamento de sangue, o maior esquema revolucionário já montado pela esquerda neste continente (D'AMICO, 1999, p. 07).
\end{abstract}

Após o golpe de 1964, os militares permaneceram no poder durante 21 anos ininterruptos. Na primeira metade deste período, sedimentou-se a presença dos militares no controle da política nacional através de um forte crescimento econômico (o polêmico milagre econômico), um considerável apoio político (a Aliança Renovadora Nacional teve grande representação no Senado, nas prefeituras e nas câmaras municipais brasileiras durante o mandato de Médici), um aparato repressor, que tinha como principal finalidade evitar o fomento de manifestações populares em defesa de melhorias sociais e da liberdade de expressão e, também, na luta contra as oposições políticas mais radicais, as quais reivindicavam a saída dos militares no poder (como um dos exemplos, o movimento guerrilheiro), além de uma maciça propaganda, que exaltou a grandeza nacional.

Contudo, ao assumir como terceiro presidente dos cincos que presidiram o Brasil no regime militar, o governo Médici deu início ao planejamento de saída dos militares do poder com a intenção de abandonar parte deste e arquitetar certas prerrogativas em um período de distensão:

Trabalharemos nesta parte com a hipótese de que o grupo castelista desenvolveu um conjunto de ações políticas, no interior do governo do Presidente Emílio G. Médici (1969-1974), visando assumir o poder e, ao longo do governo do Presidente Ernesto Geisel (1974-1979), submeter o Sistema (conforme será definido a seguir) como condição 
de empreender uma política de distensão. Esta, por sua vez, tem o duplo significado de preservar as Forças Armadas como partido militar apto a exercer o controle social e, no plano da instituição castrense, antecipar-se ao agravamento possível da crise de legitimidade que pudesse acarretar uma situação politicamente incontrolável de explosão social (OLIVEIRA, 1994, p. 60).

Golbery Couto e Silva, um dos principais estrategistas da doutrina militar brasileira no século XX e chefe da Casa Civil da Presidência da República durante os governos Geisel e Figueiredo, pertencia ao grupo castelista. Os castelistas ou o grupo da Sorbonne, como eram denominados os oficiais advindos da Escola Superior de Guerra (ESG), trabalharam no processo de distensão. O planejamento para a distensão tinha, como uma das finalidades, conduzir o processo de transição à democracia no Brasil.

Através de intensos confrontos políticos no interior do governo e instituições militares, Geisel enfraqueceu o poder da chamada linha-dura ao destituir o general Sylvio Frota, então Ministro do Exército, em 1977. Ademais, derrubou o general Ednardo D'Avilla Mello, então comandante do II Exército, local esse onde foi morto o jornalista Wladimir Herzog em 1975 e o operário Manoel Fiel Filho em 1976. Outro momento importante foi quando extinguiu o Ato Institucional $\mathrm{N}^{\circ} 5$ (AI-5), que emanava poderes extraordinários aos presidentes militares. Ao mesmo tempo em que controlava o que havia de mais repressor no regime político-militar, Geisel procurava manter o controle do processo ao relativizar a crescente figura do partido Movimento Democrático Brasileiro (MDB) nas eleições:

Enfim, com seu estilo imperial fundado nas prerrogativas de chefe de
Executivo ampliadas pela legislação autoritária, Geisel diminuiu
sensivelmente o espaço da imponderabilidade e da imprevisibilidade
institucional da ação militar, incrementando por conseqüência o grau
de previsibilidade e de ação orgânica das Forças Armadas. Legou ao
presidente Figueiredo a condução da continuidade do processo de
distensão que significa, do ponto de vista do aparelho militar, a
oportunidade para um realinhamento interno, uma correção de rota e
o preparo para novas funções. Funções políticas e militares exercidas
pelas Forças Armadas sem o ônus extraordinário da existência do
sistema (OLIVEIRA, 1994, p. 63).

A partir da atuação do governo Geisel, ações voltadas à garantia de uma saída lenta, gradual e segura permearam as políticas governamentais durante o regime de exceção. Essa remoção autocontrolada ocorreu, também, através da saída dos 


\section{Revista Brasileira de História \& Ciências Sociais - RBHCS}

Vol. $8 \mathrm{~N}^{\mathrm{o}}$ 16, Julho - Dezembro de 2016

militares nos postos de decisão da administração pública (MATHIAS, 1995, p. 92). Essa postura adotada pelas Forças Armadas foi mais uma das ações voltadas para a permanência da possibilidade de intervenção no ambiente político nacional. Elementos ativos em momentos marcantes da história republicana brasileira, os militares desenvolveram, ao longo dessas décadas, políticas, que tinham como finalidade o desenvolvimento de projetos nacionais em parceria com outros grupos políticos civis. Desde a proclamação da República, passando pelo tenentismo na década de 1920, industrialismo em 1930 e 1940, nacionalismo na década de 1950 e anticomunismo em 1960, encontramos na figura do militar a autoimagem de um agente modernizador em prol do desenvolvimento republicano:

A par de tudo isso sobrevive, desde o século XIX, uma cultura militar que propala serem os militares mais preparados do que os civis para o exercício de funções que necessitem de risco, disciplina, prazos e responsabilidade. Um cultura que diz serem eles superiores aos civis do ponto de vista moral, cívico e patriótico (D’ARAUJO, 2000, p. 15).

A identificação no meio militar, como representante desses valores, fomentou

todo um pensamento voltado para a interferência política. Essa cultura militar, construída no decorrer da conturbada formação republicana brasileira, reflete um histórico pensamento na caserna, tendo em vista um sentimento de proteção dos bons valores intrínsecos na sociedade a ser guarnecido pelos "guardiões da República":

A história da república brasileira mostra que o Exército, por suas características próprias de credibilidade, idealismo e formação, tem sido, ao longo dos anos, o recurso evocado por parcela da liderança civil e pelo próprio povo, nos momentos críticos da Pátria, daí as inúmeras interferências da Instituição na vida política nacional (FILHO, 1996, p. 07).

A politização interveniente dos militares prosseguiu nos anos após o golpe civil-militar de 1964. Em relação ao processo de distensão, havia esse papel interventor, ao analisarmos, de maneira sucinta, sua condução nos governos de Geisel e seu sucessor, João Batista de Oliveira Figueiredo, que presidiu o Brasil entre os anos de 1979 a 1985.

Após anos de repressão política, com restrições a imprensa, perseguições contra os "subversivos", torturas, assassinatos, além de dificuldades econômicas com a crise do petróleo na década de 1970, a pressão para a saída dos militares no poder 
começou a ganhar cada vez mais força. A necessidade de atenuar essas pressões advindas de boa parte da sociedade civil fez com que os militares preparassem o terreno para sua saída e entregassem o poder sem futuras represálias:

A concepção do processo de distensão controlada do regime autoritário tendo como perspectiva uma democracia de participação restrita, foi motivada por fatores essencialmente militares, em que pesem aqueles cuja natureza e compreensão demandam a referência à sociedade. Sustento a tese de que as motivações principais do processo de distensão política (e também as principais resistências que chegaram perto de inviabilizá-lo) tiveram origem na própria instituição militar (OLIVEIRA, 1994, p.107).

\section{A redemocratização brasileira e a preservação de autonomias militares}

Ativado o projeto de distensão no governo Geisel e amortecida as pressões internas da linha dura, caberia aos governos militares negociar junto com a oposição atuante na esfera político-institucional, uma transição sem grandes impactos, ou seja, uma transição pactuada. Coube a Golbery o planejamento para alijar das negociações políticas as partes radicais das duas forças. O general solicitou ao partido Movimento Democrático Brasileiro (MDB) que abafasse suas alas mais radicais, que se negavam a dialogar com o governo.

O sucessor de Geisel na Presidência, general Figueiredo, manteve o processo de distensão nas mãos das Forças Armadas. Entretanto, através de pressões advindas da sociedade civil, um novo elemento surgiu e influenciou tal processo. Promulgada em 28 de agosto de 1979, a Lei de Anistia apresentou-se como medida de encerramento das penas aos acusados de "subversão", proporcionou a volta de presos exilados, retirou das prisões indivíduos que foram detidos como "inimigos do Estado", libertou os militares de possíveis crimes cometidos, entre eles a tortura, além de ter restaurado direitos políticos e sociais; e, assim, arranjou-se uma anistia "ampla, geral e irrestrita" nos moldes conservadores dessa transiçãoํ. Ou seja, a

\footnotetext{
${ }^{1}$ Transcorridos 36 anos desde a sua adoção, a Lei de Anistia continua gerando discussões acerca de sua aplicabilidade, visto que alguns de seus artigos geram polêmica devido à suscetibilidade a opostas interpretações. Durante os últimos meses de 2008, a questão da Anistia foi amplamente debatida no cenário político nacional, gerando rachas entre os próprios integrantes do governo, que divergiram quanto à amplitude da Lei em relação aos militares, acusados de cometerem torturas contra presos políticos durante o regime militar brasileiro (1964 a 1985), e, também, as Forças Armadas, as quais alegam que a lei não devia ser alterada. Como forma de comparação, a abertura de inquéritos e a
} 


\section{Revista Brasileira de História \& Ciências Sociais - RBHCS}

Vol. $8 \mathrm{~N}^{\mathrm{O}}$ 16, Julho - Dezembro de 2016

partir da Lei de Anistia, os militares não sofreriam julgamentos após sua volta aos quartéis, pois estavam salvaguardados os direitos a não penalização por ações cometidas durante o regime.

Paralelamente, a fim de conter a ala mais radical dos militares, houve um acontecimento de proporções graves, que gerou uma negociação para que se diminuíssem, significativamente, as pressões exercidas pelos duros. O fracassado atentado ao Riocentro na cidade do Rio de Janeiro, no dia 30 de abril de 1981, véspera comemorativa do Dia do Trabalhador, serviu de base para o governo Figueiredo silenciar os colegas revoltosos com o então processo transitório:

Este episódio tem uma importância fundamental para os rumos futuros da transição. O preço pela não apuração do ocorrido foi um acordo tácito do governo com a linha dura no sentido de que esse tipo de ação seria suspensa. Estabelecia-se aqui um "contrato" através do qual as Forças Armadas, particularmente o Exército, em função do ocorrido, não seriam expostas a um julgamento público, e, em contrapartida, os duros, inconformados com os rumos da transição, não questionaram mais o regime através da subversão (D’ARAUJO, 2000, p. 07).

Os acordos formulados pelos militares resultaram em salvaguardas para a instituição nos futuros acontecimentos decorrentes da transição e da suposta consolidação democrática, como por exemplo, garantias estabelecidas na Constituição de 1988. O resultado desses conflitos de interesses refletiu-se, também, no processo de escolha para o novo presidente. Tancredo Neves (oposição) venceu as eleições indiretas através de um colégio eleitoral, mas não assumiu a Presidência devido a um grave problema de saúde, o qual levou a sua morte após mais de um mês em internação. Seu vice, José Sarney, foi empossado presidente. Após 21 anos no poder, o Brasil era governado por um presidente civil.

Ao tratarmos de uma instituição tão presente na história republicana nacional, ter visto o processo de transição para a democracia dirigido, também, pelos militares, não visualizamos a desvinculação total dessa permanente autonomia nos anos da democratização e, até mesmo, na construção da Nova República. A própria construção de um possível legado democratizante por parte das Forças Armadas, especificamente o Exército, durante os governos militares, é algo muito abordado

conclusão de julgamentos sobre esse tipo de infração cometida em outros regimes militares na América do Sul, durante o mesmo período que o caso brasileiro, ocorreu e continua acontecendo na Argentina e no Uruguai, por exemplo. 


\section{Revista Brasileira de História \& Ciências Sociais - RBHCS}

Vol. $8 \mathrm{~N}^{\mathrm{O}}$ 16, Julho - Dezembro de 2016

dentro e fora dos quartéis na Nova República e serve como exemplo dessa histórica leitura que os oficiais fazem de si mesmo como guardiões da República:

O Movimento de Março de 1964 eclodiu por pressão da Sociedade Civil e dos políticos responsáveis da época, preocupados com os rumos impostos à Nação pelos seus governantes. Os militares, e de modo especial o Exército, em atenção ao clamor público, puseram fim ao desgoverno reinante e restabeleceram a ordem e a disciplina no País, seriamente ameaçadas pelas ações e omissões verdadeiramente catastróficas de um grupo de maus brasileiros, traidores da Pátria. Com os governos militares, renasceu a autoridade como símbolo de respeito, emblema da honradez, garantia de vida decente. (...) $\mathrm{O}$ Exército, ao lado da Marinha e da Aeronáutica, tem agido como incansável guardião da ordem constitucional, mantenedor da ordem interna e da unidade da Pátria. Determinado no cumprimento de sua missão e convicto de que não há crescimento, nem evolução de uma sociedade sem o fortalecimento de suas instituições basilares (Igreja, Escola, Família e Forças Armadas) (FREITAS, 1997, p. 13).

Essa arquitetura de valores militares hierarquicamente superiores aos valores civis é trabalhada desde o início da carreira, quando o cadete adentra na academia militar e interage-se de corpo e alma ao mundo militar (CASTRO, 2004, p. 12). A partir da dicotomia entre os dois mundos, os militares estabeleceram, ao longo de sua história, um conjunto de valores (hierarquia, disciplina, ordem, entre outros), que são supervalorizados na caserna e destoantes dos valores cotidianos do mundo civil. Afinal de contas, na visão militar, persistente na Nova República, o soldado é aquele quem põe em risco sua própria vida para defender a pátria, a nação, os valores nacionais:

Acredita-se que o papel desenvolvido pela Instituição ao longo do processo histórico da Nação, permite inferir que o EB, desde suas origens, não tem sido um ente estranho na vida da sociedade brasileira. E, se assim tem ocorrido, não foi por obra do acaso ou de fatores esporádicos ou conjunturais, mas, sim, em face de uma contínua interação e de uma sólida identificação da Instituição Militar Terrestre com o pensamento, crenças e valores dos segmentos majoritários da nacionalidade (GONÇALVES, 2006, p. 59).

Imbuídos desses valores, o estamento militar constituiu a autoimagem de guardiões da República. O Clube Militar, fundado em 26 de junho de 1887, e que durante o século $\mathrm{XX}$ foi partícipe influente em diversas conjunturas políticas da 


\title{
Revista Brasileira de História \& Ciências Sociais - RBHCS
}

Vol. $8 \mathrm{~N}^{\mathrm{o}}$ 16, Julho - Dezembro de 2016

República, intitula-se como "A Casa da República².” A superioridade exaltada pelos militares em relação ao mundo dos paisanos e o controle sobre a Defesa, ganhou corpo logo na origem da República. Mesmo após o fim desse regime, a repercussão desse período na recente democracia instalada manteve o status moderador dentro do Exército:

\begin{abstract}
Ao Exército Brasileiro enquanto Instituição, condutor maior da coerção ao terrorismo naquela época, cabe hoje a serenidade de ter muito bem cumprido a sua missão em prol do restabelecimento da normalidade democrática. Impediu inicialmente uma tentativa de tomada de poder mediante a infiltração comunista na máquina governamental e depois sepultou as aspirações daqueles que pretendiam implementar uma doutrina política estranha às tradições culturais brasileiras, agora fazendo uso das armas. Tudo com uma perda ínfima em termos de vidas, se comparado ao ocorrido em outros países, particularmente àqueles perpetrados em favor do Movimento Comunista Internacional ou em relação a outros regimes militares instalados para combater a subversão na América do Sul (SILVA, 2003, p. 107)
\end{abstract}

\section{O governo Sarney e a Constituinte de 1988}

Desgastado pelas inúmeras denúncias de abusos contra membros da sociedade, entre elas assassinatos e tortura no decorrer do Regime Militar, e por uma forte crise econômica iniciada na segunda metade da década de 1970, os militares foram projetando sua saída a partir do governo Geisel. Entre idas e vindas, os governos militares prepararam, através de negociações com a oposição, representada pelo $\mathrm{MDB}$, a famosa transição lenta, pactual e segura. As eleições presidenciais indiretas ocorridas em janeiro de 1985 corroboraram para isso.

Político vinculado ao partido de apoio do Regime Militar por vários anos (a Aliança Renovadora Nacional), o candidato à vice-presidência, José Sarney assumiu a presidência da República, interinamente, no dia 15/03/1985, pois o candidato eleito, Tancredo Neves, adoeceu e não chegou a assumir o cargo. Com a morte de Tancredo em 21/04/1985, pairou sobre o ambiente político brasileiro a possibilidade de estar ocorrendo uma situação ilegal referente à posse de Sarney, haja vista que não poderia assumir em definitivo a presidência, pois o presidente eleito não recebeu a faixa. $\mathrm{O}$ político maranhense recebeu apoio por parte dos militares em detrimento da possibilidade do então presidente da Câmara dos Deputados, Ulysses Guimarães,

${ }^{2}$ Disponível em: http://www.clubemilitar.com.br/. Acesso em 18/05/2015. 
Revista Brasileira de História \& Ciências Sociais - RBHCS

Vol. $8 \mathrm{~N}^{\mathrm{o}}$ 16, Julho - Dezembro de 2016

desafeto dos militares, receber esse posto. Em depoimento, o ministro do Exército durante o governo Collor, general Carlos Tinoco Ribeiro Gomes, ilustrou o desenho desse apoio:

Aí, o general Leonidas pegou a Constituição, foi para uma reunião dos ministros com o Sarney e mostrou que o normal seria o vicepresidente assumir. Havia quem achasse que não, porque o Tancredo não tinha assumido, mas a palavra dele dirimiu as dúvidas (CASTRO; D’ARAUJO, 2001, p. 202).

A participação do general Leonidas significou uma determinada liderança na transição política, pois o próprio vice-presidente possuía dúvidas acerca do apoio político ao assumir, eventualmente, a presidência. A partir da análise de um major do Exército, a hesitação de Sarney contribuiu para enaltecer a figura de Leonidas:

\begin{abstract}
Durante aquela noite, Sarney repetira esse mesmo desejo várias vezes, para mais de um interlocutor: achava que não tinha legitimidade para assumir, julgava que se deveria esperar que o presidente eleito Tancredo Neves, internado no Hospital de Base, se recuperasse para tomar posse. Leônidas perdeu a paciência e deu uma bronca naquele que seria o seu comandante a partir do dia seguinte: "Olha, Sarney, você sabe os problemas graves que estamos enfrentando. Você não pode mais criar nenhum caso. Todos estão unânimes nessa decisão.” O general terminou, então, de forma definitiva: "Boa noite, presidente!” As Forças Armadas são as fiadoras da Nova República (FREITAS, 2008, p. 62).
\end{abstract}

O que poderia ter sido um mandato interino transformou-se em um longo mandato de cinco anos e serviu de base para os interesses militares na futura Constituinte, além de propiciar a permanente intervenção em assuntos não relacionados à esfera militar:

No final de 1985, o mapa político se tornou claro: as Forças Armadas haviam deixado o governo mas não o poder. Essa era uma situação excepcional para as Forças Armadas, pois ela se isentavam de carregar o ônus de governar um país em crise mas mantinham o poder de veto sobre decisões que afetassem seus interesses (ZAVERUCHA, 1994, p. 189).

Os militares mantiveram seu poder decisório logo após o fim do Regime Militar, configurando um quadro tutelar, onde os interesses da corporação castrense muitas vezes prevaleciam em contraposição ao pulverizado poder civil. A tutela empreendida 


\section{Revista Brasileira de História \& Ciências Sociais - RBHCS}

Vol. $8 \mathrm{~N}^{\circ}$ 16, Julho - Dezembro de 2016

pelos militares no governo Sarney foi mais um pacto político para salvaguardar os interesses dos homens de farda. Ao mesmo tempo em que o primeiro governo civil pós-Regime Militar recebeu apoio da caserna, suas políticas de governo foram restringidas.

Um dos principais retratos dessa situação tutelar foi a participação do Ministro do Exército, general Leônidas Pires Gonçalves, em vários processos decisórios no governo Sarney, institucionalizando suas opiniões acerca dos problemas nacionais de maneira constante. O general tutelou muitas ações empreendidas pelo governo, sociedade e Congresso Nacional, distanciando, ainda mais o poder político e o aparelho militar. Houve intromissões na política externa ao afirmar que o Brasil construiria a arma nuclear caso suspeitasse que a Argentina, então parceira no processo de formação do Mercosul, estivesse planejando sua construção. Internamente, advertiu membros políticos a abrigarem as propostas militares na Constituição, entre elas, a conservação do regime presidencialista contra a proposta a favor do parlamentarismo (OLIVEIRA; SOARES, 2000, p. 21). Seu posicionamento foi decisivo na conservação do processo político iniciado no governo Geisel, ao preparar o terreno e manter prerrogativas e privilégios militares na nova Constituinte.

A presença militar no que tange a interferência na política do país permaneceu após o Regime Militar. Podemos constatar dessa presença, a continuação dos assuntos ligados à defesa e segurança no país sob as mãos das instituições castrenses, além de preservarem para si a histórica visão militar de guardiões da República brasileira. Ou seja, notamos uma situação paradoxal na formação da Nova República no Brasil: dentro de um sistema democrático, a gerência de políticas, as quais deveriam girar em torno dos interesses de toda a sociedade, permaneceu restringida basicamente aos interesses de um pequeno grupo desse conjunto. Além dos controles nessas duas esferas, os militares trabalharam para manter certos privilégios de carreira, combateram a reforma de ampliação dos direitos da Lei de Anistia de 1979, entre outros arranjos, costuraram sua autonomia na Nova República. Ao manter parte de seu peso decisório no governo Sarney, os militares puderam mover seus interesses durante o processo de formação da Constituinte.

Nesse jogo de interesses, entre idas e vindas, o aparelho militar somou um bom número de conquistas através do seu lobby via assessorias. O que se viu nos anos de maturação da Constituinte foi a busca, por parte do bloco militar, em manter 
sua autonomia. Mais uma vez, o Exército, juntamente com o Conselho de Segurança Nacional e o Estado-Maior das Forças Armadas, definiu esses parâmetros na Subcomissão de Defesa da Assembléia Nacional Constituinte. O dirigente dessa subcomissão foi o deputado federal Ricardo Fiúza, político conservador, que interveio favoravelmente em prol dos interesses dos homens de farda, mas não possuía grandes conhecimentos sobre o assunto, o que possibilitou um grande espaço de atuação em prol desses interesses (ZAVERUCHA, 2005, p. 60). A autonomia se daria através da possibilidade das Forças Armadas intervirem na defesa interna, relativizarem a atuação do presidente como comandante-em-chefe e manterem o status de ministros aos principais líderes de cada Força.

Em relação ao papel das Forças Armadas na Constituição de 1988, o legado interventor visto em constituições passadas, no alinhamento com a Doutrina de Segurança Nacional e no governo autoritário, que se arraigou durante 21 anos à frente do poder, esteve presente no documento ao delegar às Forças Armadas o poder político de atuação dentro do território nacional contra possíveis inimigos internos:

Uma outra questão que deve ser considerada é a separação entre os conceitos "política de defesa" e "segurança interna". Tradicionalmente, esses conceitos constituem domínios distintos: a política de defesa tem orientação externa e é tarefa das Forças Armadas, enquanto a segurança interna pertence à área da polícia. [...] O Brasil apresenta uma situação mista. Enquanto o conceito de segurança nacional está ausente da Constituição de 1988 e as polícias civil e militar estão claramente incumbidas da segurança pública (art. 144), o papel das Forças Armadas é definido de maneira ambígua (SANTOS, 2004, p.).

Assegurada essa função constitucional desde a Comissão Afonso Arinos, considerada uma questão inegociável pelos militares, o artigo 142 da Constituição de 1988 foi redigido da seguinte forma:

As Forças Armadas, constituídas pela Marinha, pelo Exército e pela Aeronáutica, são instituições nacionais permanentes e regulares, organizadas com base na hierarquia e na disciplina, sob a autoridade suprema do Presidente da República, e destinam-se à defesa da Pátria, à garantia dos poderes constitucionais e, por iniciativa de qualquer destes, da lei e da ordem (BRASIL, 1988).

Portanto, ao invés de atuarem como instrumento da sociedade no uso da força ante uma ameaça externa, as Forças Armadas adquiriram o direito de utilizar essa 


\section{Revista Brasileira de História \& Ciências Sociais - RBHCS}

Vol. $8 \mathrm{~N}^{\mathrm{O}}$ 16, Julho - Dezembro de 2016

força e exercer um poder político interno, um poder de polícia. Apesar da suposta submissão à autoridade suprema na figura do líder do Executivo, o Congresso, em 1988, também conferiu aos poderes Legislativo e Judiciário o direito de convocar as Forças Armadas para intervirem em casos de crise interna. No fim do mesmo o ano já colher-se-ia o resultado funesto dessa medida.

No dia 07/11/1988, trabalhadores da Companhia Siderúrgica Nacional (CSN), localizada na cidade de Volta Redonda (RJ), entraram em greve reivindicando melhores condições sócio-econômicas. Dois dias depois, o juiz da terceira Vara Cível de Volta Redonda, Moises Cohen, redigiu um mandato de manutenção de posse e solicitou ao Exército, juntamente com a Polícia Militar, a reintegração da CSN. Soldados especializados no aniquilamento do inimigo em uma guerra, o grupo militar, comandado pelo general José Luis Lopes, realizou com sua função e matou três grevistas. Em entrevista, o general Lopes afirmou que possuía dois motivos para atuar no evento: "para reestabelecer a ordem porque houve insubordinação civil e para preservar o patrimônio que até agora não sofreu danos (FOLHA DE S. PAULO, 1988)".

Mais uma vez, na história das constituições brasileiras, esse mecanismo de atuação sobrepôs à tentativa de formação de um espaço republicano. Na visão de dois oficiais militares do Exército essa relação entre a atuação interna e a preocupação com a defesa externa do país foi algo construído ao longo dos anos no Brasil e sua incorporação subentende-se completamente assimilada como função da Força:

\footnotetext{
Historicamente, as posturas de Defesa Externa e Interna Brasileiras se confundem em vários aspectos, por razões que vão desde as dimensões continentais do País até as características culturais do seu povo. Não há um sistema nacional integrador de todos os campos do poder nacional em prol da segurança interna. Com a finalidade de sanar esta deficiência, de acordo com suas possibilidades, o Exército Brasileiro, com base em suas experiências mais recentes, desenvolveu o conceito de "Segurança Integrada", através do qual busca aumentar a eficiência de seu desempenho em prol da Garantia dos Poderes Constitucionais, da Lei e da Ordem (PERLINGEIRO; PIRES, 1996, p. 71).
}

Interessante notar que, no trecho citado, os militares atribuem a confusão entre defesa externa e defesa interna, entre outros motivos, às "características culturais” do povo brasileiro. Por se tratar de uma instituição tão atuante no cenário político republicano, muitas vezes proclamando-se a voz do povo, muitos dos valores 


\section{Revista Brasileira de História \& Ciências Sociais - RBHCS}

Vol. $8 \mathrm{~N}^{\mathrm{o}}$ 16, Julho - Dezembro de 2016

(hierarquia, disciplina) transmitidos pelas Forças Armadas são colocados como intrínsecos à sociedade brasileira.

Exercido o direito constitucional de defesa interna, estabelecido na Comissão Afonso Arinos, os militares reivindicaram outros direitos vinculados à manutenção da ordem interna. Entre esses, a permanência das Polícias Militares na ação contra a violência e a preservação da ordem pública, e a manutenção do regulamento, que atribui a essas instituições o estatuto de reservas e forças auxiliares do Exército em situações de graves conflitos. De acordo com o artigo 144, "as polícias militares e corpos de bombeiros militares, forças auxiliares e reserva do Exército, subordinamse, juntamente com as polícias civis, aos Governadores dos Estados, do Distrito Federal e dos Territórios” (BRASIL, 1988). A possibilidade das polícias militares atuarem como forças auxiliares foi mais uma contribuição do legado autoritário vigorante no decorrer do Regime Militar.

\section{CONCLUSÃO}

O objetivo em analisar tais processos políticos auxilia-nos a ilustrar o modo como os militares preparam-se para deixar o poder e voltaram aos quartéis com uma bagagem considerável de autonomia sobre a defesa nacional e a sobrevivência de valores atribuídos a antiga Doutrina de Segurança Nacional, o que garantiu aos militares a possibilidade de atuarem na defesa interna do país e manterem um pensamento não condizente com os novos tempos democráticos. Essas autonomias foram construídas ao longo desse processo. Apesar das divergências internas entre as Forças, o meio castrense, com preponderância do Exército, atuou em várias frentes e marcou presença nas formulações políticas, a partir de seu lobby nas comissões parlamentares e sua ação tutelar durante o governo Sarney. Além do mais, essas prerrogativas foram conquistadas, também, devido à maneira que boa parte da classe política tratou o tema durante a Constituinte:

No caso brasileiro, as FFAA conseguiram conservar prerrogativas e níveis de autonomia que lhes permitem localizar fissuras no quadro político nacional, mantidas abertas pela ignorância e pelo desinteresse da classe política nesses temas. Por tais fendas, facilmente detectadas, os militares infiltram-se para disputar protagonismo político em decisões nacionais (SAINT-PIERRE; WINAND, 2007, p. 44). 
Esse “protagonismo político em decisões nacionais" dos militares colaborou no enfraquecimento do processo democrático brasileiro, pois o controle civil não se fez presente e, no momento em que uma nova Constituição era formulada, a chance de assumir esse papel foi delegada, novamente, ao estamento militar. A permanência dessas prerrogativas autoritárias em um governo democrático não se deu, apenas, através do lobby militar, pois, assim como a tomada de poder em 1964 foi feita através de um golpe cívico-militar, sua transição à democracia foi pactuada e o que esteve em jogo foi à preservação de interesses políticos entrelaçados ao Sistema Político e as Forças Armadas. Muitas das intervenções militares nas ações de garantia da lei e da ordem na Nova República, solicitadas por membros dos diversos poderes políticos, evidenciaram como esse sistema político ofereceu ao estamento militar, a legitimidade da conservação de sua autonomia e seu pensamento autoritário. O que percebemos em nossas leituras sobre esse período foi que a preservação da autonomia militar, consentida pelo Sistema Político, reinaugurou um regime político fragilizado democraticamente e sem uma política clara sobre os interesses brasileiros em defesa. A escassa participação da sociedade na discussão sobre a defesa também facilitou essa autonomia. Ao acompanharmos esses fatos e a interpretação castrense na Nova República, constatamos que não houve um interesse da sociedade brasileira na questão da defesa nacional. Tanto os desinteresses da população e de seus representantes no poder, quanto à participação dos militares em não perderem seus espaços na condução dessas políticas, dificultaram a formação de uma política de defesa alicerçada nos interesses nacionais vinculados ao regime democrático, assim que esse esteve vigente ao término do regime militar.

\section{Bibliografia}

CARVAlho, J. M. de. Forças Armadas e Política no Brasil. Rio de Janeiro (RJ) Ed: Jorge Zahar. 2005.

CASTRO, C. \& D’ARAUJO, M. C. (Org.). Militares e política na Nova República. Rio de Janeiro (RJ). Ed: FGV. 2001.

D'ARAUJO, M. C. Ainda em busca de identidade: desafios das Forças Armadas na Nova República. CPDOC. Rio de Janeiro (RJ). 2000. 
MARQUES, A. A. Concepções de Defesa Nacional no Brasil: 1950-1996. Campinas, SP: Dissertação (mestrado), 2001.

MATHIAS, S. K. Distensão no Brasil: o projeto militar (1974-79). Campinas (SP). Ed: Papirus. 1995

OLIVEIRA, E. R. de. De Geisel a Collor. Forças Armadas, transição e democracia. Campinas (SP). Papirus, 1994.

\& SOARES, S. A. Forças Armadas, direção política e formato institucional. In: CASTRO, C. \& D'ARAUJO M. C. (Org.) Democracia e Forças Armadas no Cone Sul. Rio de Janeiro (RJ). Ed. Fundação Getulio Vargas, 2000.

SAINT-PIERRE, H. L. \& WINAND. É. O legado da transição na agenda democrática para a defesa: os casos brasileiro e argentino. In: SAINT- PIERRE, H. L. (Org.). Controle civil sobre os militares e política de defesa na Argentina, no Brasil, no Chile e no Uruguai. São Paulo. Ed: UNESP. 2007.

SANTOS, M. H. de C. A nova missão das Forças Armadas latino-americanas no pós-Guerra Fria: o caso do Brasil. Revista Brasileira de Ciências Sociais vol.19. n.54. FEV/2004

ZAVERUCHA, J. Rumor de Sabres - Controle civil ou tutela militar? Estudo comparativo das transições democráticas no Brasil, na Argentina e na Espanha. São Paulo (SP). Ed: Ática. 1994.

.FHC, forças armadas e polícia - entre o autoritarismo e a democracia (1999-2002). Rio de Janeiro, RJ: Record, 2005.

\section{Fontes militares (dissertações e teses)}

D’ AMICO, F. A. N. 31 de março de 64 - Versão atual da mídia e reflexos nas gerações futuras. Curso de Política, Estratégia e Alta Administração do Exército (Monografia). ECEME. 1999.

FILHO, H. de S. A participação do Exército na vida política nacional: Da proclamação da República ao fím da Era Vargas. Monografia. Curso de Altos Estudos Militares. ECEME. 1996.

FREITAS, J. de C. O papel do Exército na Sociedade Brasileira no próximo século. Rio de Janeiro (RJ). Curso de Política, Estratégia e Alta Administração do Exército (Monografia). ECEME. 1997.

FREITAS, O. R. de. J. A participação políticas dos ministros do Exército de 1964 a 1985. Rio de Janeiro (RJ). Trabalho de admissão no Curso de Ciências Militares (ECEME). 2008.

GONÇALVES, L. F. O relacionamento do Exército com segmentos civis da sociedade, no contexto das relações civis-militares e o papel da Fundação 
Revista Brasileira de História \& Ciências Sociais - RBHCS

Vol. $8 \mathrm{~N}^{\mathrm{o}}$ 16, Julho - Dezembro de 2016

Cultural Exército Brasileiro. Rio de Janeiro (RJ). Curso de Ciências Militares (Dissertação). ECEME. 2006.

PERLINGEIRO, R. B.; PIRES, C. A. R. P. Diretriz Estratégica de Defesa Interna (SIPLEX-5). Rio de Janeiro, RJ: ECEME, 1996.

SILVA, F. C. M. O Exército Brasileiro e a sua Vocação para o Ideal Democrático. Curso de Mestrado em Ciências Militares (Dissertação). Rio de Janeiro (RJ). ECEME. 2003.

Fontes secundárias

BRASIL. Constituição da República Federativa do Brasil. Brasília (DF). 1988.

FOLHA DE S. PAULO. Confrontos entre Exército e metalúrgicos causa 1 morte.

Disponível em: http://acervo.folha.com.br/fsp/1988/11/10/340 - Acesso em 21/o8/2015.

Recebido em Agosto de 2015

Aprovado em Agosto de 2016 